\title{
Introducing the Meaning of Batik through Game and Appearance in Virtual Reality
}

\author{
Bayu Widiantoro and Ag. Dicky Prastomo \\ Visual Communication Design, Soegijapranata Catholic University \\ dicky.prastomo@unika.ac.id
}

\begin{abstract}
Batik is not just visually but also philosophically enticing. A brief history in 1755, in the era of "Keraton Surakarta" and "Keraton Yogyakarta", each kingdom has developed their own style including motif and coloring. Making a Batik is not just simply decorating, it is also form a repository of beliefs and values. Youth or young one, need to examine and understand Batik with spesific meet their ways. A digital native generations. Visual communication research design offers a case study and visual etnography or visual decoding to describe, to compare, and to evaluate the pattern, beliefs and values. Overall, analysis of findings would clearly indicate that most of the target audiences are not interested to know what the meaning of Batik meaning, but they relay on smartphone gaming as daily activity. The like to know things through 2 dimesional game.
\end{abstract}

Keywords: batik, motif/pattern, game, beliefs and values

\section{INTRODUCTION}

According to the Indonesian dictionary, BATIK is the pictorial fabric. It is processed in a certain way by writing on the cloth. In Javanese, BATIK comes from the word "MBA" and "TIK". The word "MBA" in Javanese means writing, while the word "TIK" refers to the word dot, so the meaning of the word batik is to write a point. But, Batik is not just visually but also philosophically enticing.

A brief history in 1755, in the era of "Keraton Surakarta" and "Keraton Yogyakarta", each kingdom has developed their own style including motif and coloring. Making a Batik is not just simply decorating, it is also form a repository of beliefs and values. Teenagers, need to examine and understand Batik with spesific meet their ways, a digital native generations.

This paper ilustrates how a game and appearance in virtul reality can help teenagers, 15-18 years old understanding the meaning of BATIK. The paper examines the significance of style of Batik including pattern/motif and coloring. Visual communication research design offers a literature reviews, observations, direct interview and questionnaire to obtain information directly from research target. So, they could describe, compare, evaluate and understanding the Batik's pattern, beliefs and values. 


\section{BATIK: PART OF INDONESIAN CULTURE}

Batik is a part of Indonesian history and culture. In Indonesia batik known since the early 18th century and became very popular at the end of the 18 century. The Palace and common people has been produced and used as clothing. There are various types of batik. One of them is Batik Jogja. Batik Jogja made at a traditional city, Yogyakarta. Batik Yogyakarta is a batik that gets a big influence from the palace. It has a form that mostly in a geometric pattern, full of order, regularity, and rules. Certain batik motifs should not be used by ordinary people and only be used by the royals. Some batik motifs also can not be worn on any event. Each motif has its own meaning and purpose so it can not be imposed carelessly. The motifs are not only as a picture or ornament, they made as a pray or showed the people feels when they used it.

Batik as Indonesian culture has been recognized by the world. UNESCO has recognized batik as a heritage of humanity for oral and non-material culture. Batik as a heritage of humanity for oral and non-musical culture means not just batik as a piece of fabric that is done with batik technique but has a deeper meaning. Batik is recognized as a reflection of expectations that reflect socio-cultural identity. The reflection of social identity of batik culture is conveyed through the diversity of motives meaning.

Indonesian society is now more proud, loving, and interested in batik. This is evident from various things one of which is the people of Indonesia both old and young have made batik as their clothing choice. There are many choices of batik clothing so that the people of Indonesia have a lot of options ranging from batik motif to batik fashion model. In the past, the selection of batik can not be done carelessly, the meaning of batik motif become the main consideration. But in its development the process determines the current batik clothing is more directed to the likes of batik motifs and fashion models. The meaning of batik motif is not a consideration in choosing batik clothing.

\section{MISSED PERCEPTION}

We made observations on batik clothes worn and owned by 50 teenagers. Batik clothing from all teenagers has a variety of motives. But $80 \%$ of adolescents have batik clothes with machetes parang barong and parang rusak, a combination from the old motif palace. The forbidden motif for common people. 


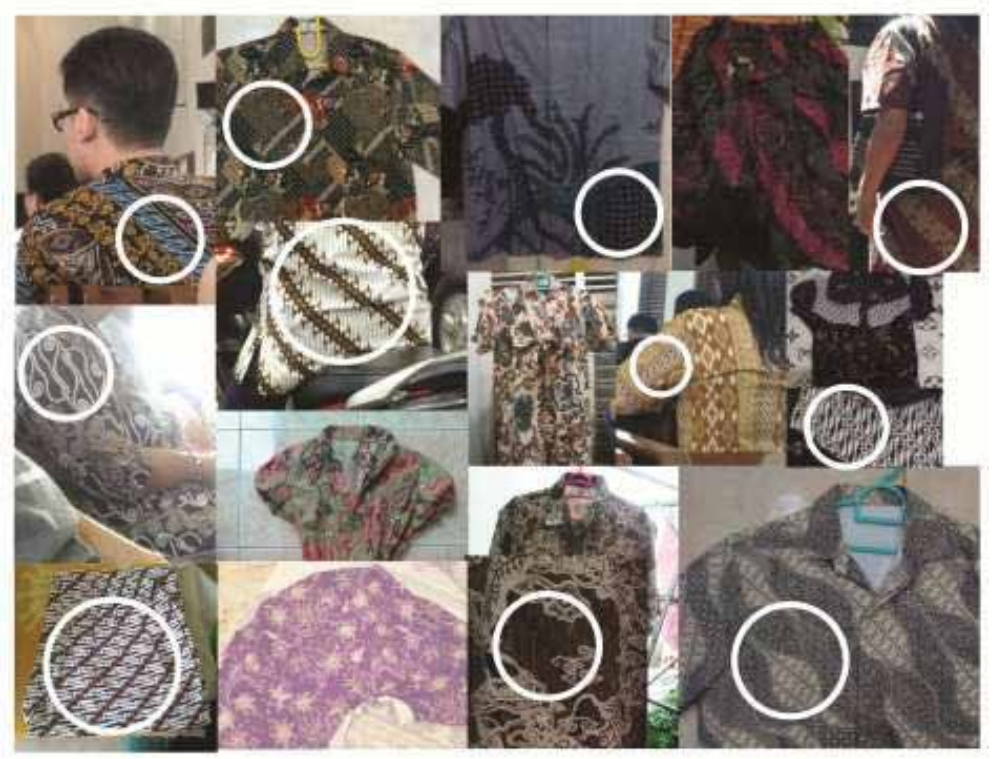

Picture 01. Personal documentation on contemporary batik used by teenagers.

In 1785 Sri Sultan Hamengkubuwono I issued a ban on the use of parang batik motifs outside the palace. in 1927 Sri Sultan Hamengkubuwono VIII confirmed the ban. Parang batik motif can not be worn by ordinary people, can not be worn outside the palace and can not be worn on any event. The motive of the barong machete (created by the king of mataram on the basis of his life during the reign of the kingdom) may only be imposed by the king during his reign in the palace in the hope that the king can lead wisely and justly. The broken machete motif may only be worn by the royal family in state events, not for other events. Parang machete motive has a meaning that the wearer can control the lust and dispel the nature of evil from within to remain wise. The teenagers clearly do not understand the meaning of real machete batik motif. According to existing rules the teenagers can not wear clothes with machetes motif daily.

In today's rules of use of some batik motifs are not as strict as in antiquity but that does not mean the meaning of batik motifs can be forgotten just like that. UNESCO also encourages the entire community to continue to recognize, document, protect, promote and revitalize batik as Indonesian culture. That means the whole of batik should be recognized and protected including the meaning of batik motifs.

\section{THE PROBLEMS}

There are many choices of batik clothing that exist in the market. Mostly, people are free to choose with a certain consideration. Unlike ancient times, today's consideration is based on the likes of motifs and fashion models. The meaning of batik motif is no longer a consideration in choosing batik clothing. Surely, the meaning of batik motif is a very important element that must be considered because the meaning of batik motif is an integral part of batik as Indonesian culture. 
The meaning of batik motif has begun not to be a major consideration in choosing batik clothing. Some parents know some meaning of batik motif. But most teenagers do not know the meaning of batik motifs. Teenagers are the next generation, the generation that will preserve batik as Indonesian culture. If they do not understand the meaning of batik motifs, in the future will appear as motif cloth without meaning. Batik as a part of Indonesian Culture must be preserved continuously.

\section{THE NEXT GENERATION: WHY TEENAGERS?}

The next generation, teens will grow up and become leaders in the future. Teenagers are the generation that will preserve the culture of batik. Therefore, adolescents must have the right knowledge about batik so that batik will continue to be known right also by the people of the future. This paper focuses on 15-18 years old teenagers. As an insight ilustration: Kevin (16 years old) is a private High School student. Currently Kevin has a smartphone that he has since he was sitting on the bench IX class. This year he plans to sell his smartphone and buy the latest smartphone. Kevin is a teenager who has many friends. The Smartphone did not stop vibrating because the social media that is active in smartphonenya always flooded with the chat from his friends. Kevin routinely always play games from social media that he downloaded. Since getting an invite from his friend and knowing that many of his friends are also playing he feels interested to come into play.

In this study, there are several reasons why the target will be teenagers aged 1518 years : (1) Psychological factors ; Teens have started to play an active role in making decisions for himself. Knowing the right information is expected to make decisions more precise. (2) Positioning ; Information about the meaning of batik that looks boring and unattractive to come up with a more fun and cool style. (3) Reason to Believe ; Basically the meaning of batik is not difficult to understand because it is the practice of cultural values that we do not realize already exist in the community today. (4) Tone and Manners ; The meaning of batik appears as a friend to the target consumer namely geometric motifs and non geometric motifs so that the target consumers will be more comfortable in touch with it.

\section{PROBLEM STATEMENT}

This study aims to introduce and provide and understanding of the meaning of batik Jogja motif. By knowing and understanding its meaning as we could expected: teens become aware and understand about the meaning of batik motifs and Batik in the future will not lose meaning.

Based on the scope of the research, we formulate a question; How to design a game to give an understanding about the meaning of batik motif for teenagers? 


\section{METHODOLOGY}

The literature review was conducted to obtain preliminary information as supporting other research methods such as direct interview, observation, and questionnaire. Direct interviews conducted to obtain data on the meaning of batik motifs from parties who understand well the meaning of batik motifs. Before conducting direct interviews, a literature review is needed to strengthen basic knowledge. By conducting direct interviews the information obtained will be more appropriate.

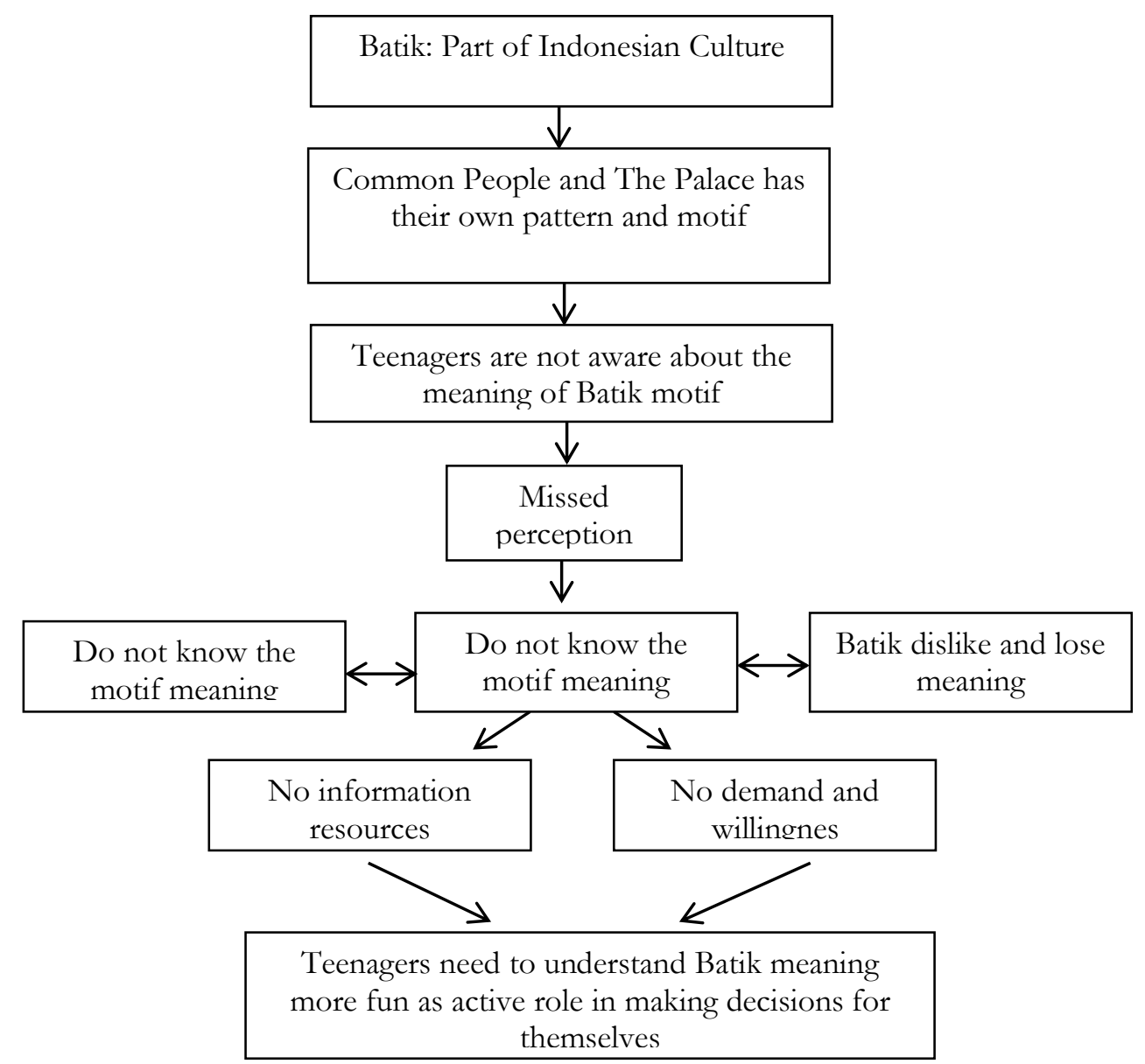

Scheme 01. Logic thinking of the problem and solution

Observations conducted to find out the behavior of batik motifs use research target. Before doing the observation need to do literature review with the aim to equip themselves with basic knowledge so that the observation can run optimally. The questionnaire was conducted to obtain information directly from the research target. To prepare a questionnaire it is necessary to conduct a literature review in order to prepare a questionnaire.

This scheme, describe and show the logic structure of common problem and solution for it. Teenagers need to understand Batik meaning more fun as active role in making decisions for themselves 


\section{REFERENCES AND THEORY}

Communication flow theory (Fiske: 2012) is used in the design of message delivery flow. The message delivery flow will be applied to the game flow to be designed. By conveying the message with the proper flow will simplify the delivery and minimize complaints in the delivery process. It is one way commmunicatioan model and interactive model. Meanwhile Robert M Gagne (Gagne: 1973) describes the process of learning from techniques to how to convey information. Teenagers could used to complement the flow of a game's flow message.

Developmental Psychology is offered by Elizabeth B. Hurlock (1956) as a basis to determine the state of target psychology. In this study, the target among teenager between 15-18 years old. Its urgent to understand the meaning learned from Batik motif. Hamzuri (1989) sugested how to make batik tulis coherent from beginning to end, until at the end displayed the types of batik cloth motif classic with brief explanation of meaning.

The explanation of meaning is enrich with emphasis on the technique of depiction of each basic motif, the characteristics of the type of motif, and the standard description of each basic motif. Each of the decorations described by Sri Soedewi (2011) according to the shape base and described one by one from each group type. All of these explanations will be used as the basis for visual design. Taking into account the right rules will result in a good design and will not lead to misperceptions or misconceptions.

All references about Batik will be used as game basis. The division of player (Crawford: 1997) type will be used as the basis of data processing. The type of player and his behavior in play can be the basis for deciding what kind of game is appropriate. Satisfactory game criteria, component user interface, player perspective type, and game menu type are used as the design basis. The whole theory is an important component that must be considered in designing a game. Taking into account the whole theory will result in an easy and fun game design to be operated by each type of player. By matching the type of player and the type of play the appropriate way it will facilitate the interest of players and facilitate the delivery of the desired message and determine the genre of the game.

Game Plants Vs Zombies and Happy Mall Story are used as a comparison in terms of genres. Plants Vs Zombie is played by strategizing. At the beginning of the game the players have a mission to keep Zen home so zombies can not enter and eat their brains. Players start the game by choosing what crops to plant in the park to fight the zombies who will try to enter the Zen house. Broadly speaking how to play Plants Vs Zombie game is to devise a strategy to protect something from the enemy. 


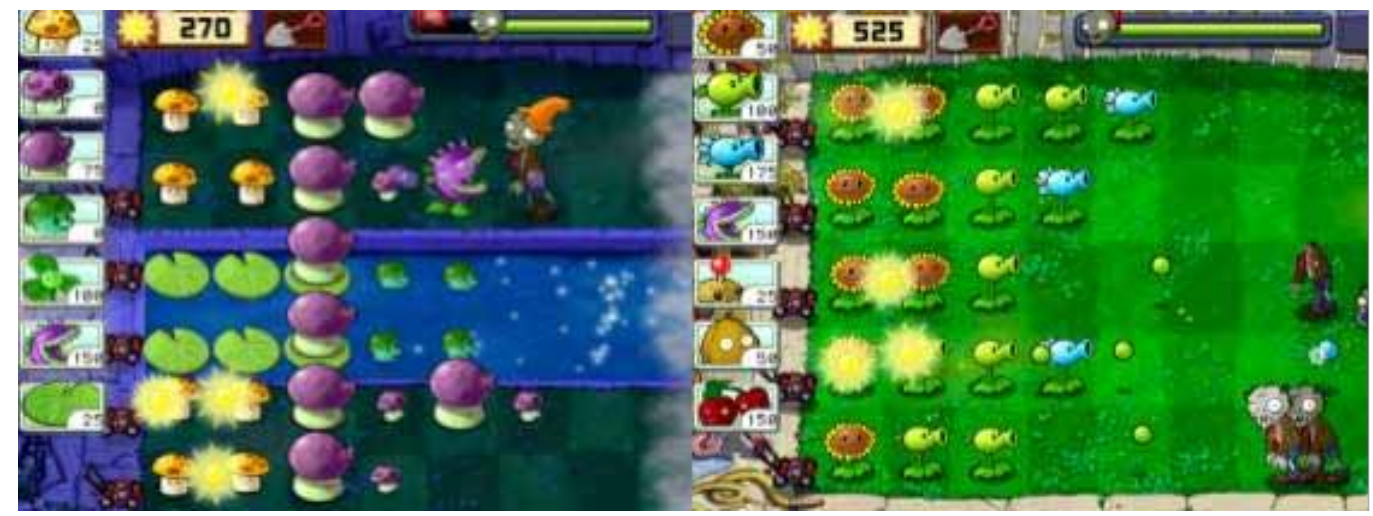

Picture 03. Captured documentation from Plant vs Zombie

The expression of each character in Happy Mall Story always looks smiling and happy even when the character is upset (the buyer's character is upset because of long queuing). A cheerful expression of all the characters gives a happy impression on this game.

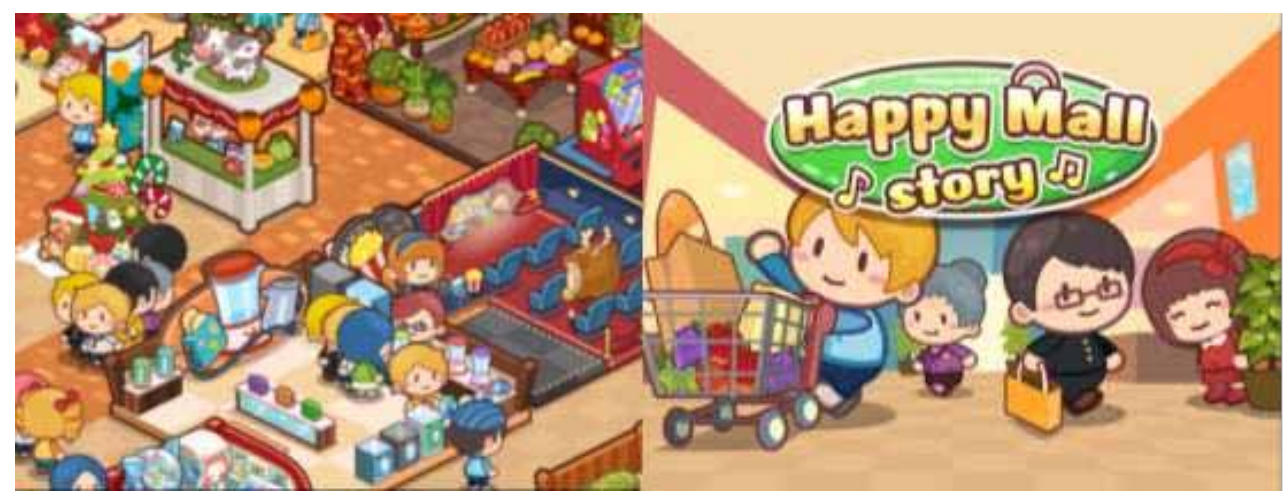

Picture 03. Captured documentation from Plant vs Zombie

\section{RESULTS AND DISCUSSION}

\section{THE LACK OF UNDERSTANDING MEANING OF THE MOTIF}

When the teenagers was asked what is the the meaning of batik motif, $36 \%$ of respondents appeal to the absence of information and $64 \%$ of respondents said they were not interested in finding out. From these results can be concluded that the target of research is not interested to know what the meaning of parang batik motif. Instead of the meaning is very important. After this questions, $88 \%$ of respondents did not know that there is batik motif that can not be used arbitrarily and $92 \%$ of respondents do not know the rules of using batik motifs especially Batik Parang. 


\begin{tabular}{|l|l|l|l|l|l|}
\hline $\begin{array}{l}\text { Knowing } \\
\text { Batik Info }\end{array}$ & $\begin{array}{l}\text { Knowing } \\
\text { Batik Info }\end{array}$ & $\begin{array}{l}\text { Knowing } \\
\text { of Use } \\
\text { motif }\end{array}$ & $\begin{array}{l}\text { Knowing } \\
\text { of Use } \\
\text { motif }\end{array}$ & $\begin{array}{l}\text { Knowing } \\
\text { restriction }\end{array}$ & $\begin{array}{l}\text { Knowing } \\
\text { restriction }\end{array}$ \\
\hline $\mathbf{3 6} \%$ & $\mathbf{6 4 \%}$ & $\mathbf{1 2 \%}$ & $\mathbf{8 8 \%}$ & $\mathbf{8 \%}$ & $92 \%$ \\
15 & 27 & 6 & 44 & 4 & 46 \\
respondents & respondents & respondents & respondents & respondents & respondents \\
\hline
\end{tabular}

Today the results can be said that the target research does not know that there is batik motif that can not be used arbitrarily and also do not know the rules of the use of batik motifs machete. It can be concluded that the research target does not have a deep understanding. The target of research has not been able to achieve understanding. The level of understanding of new research targets is limited to just know, and just to wear the cloth.

\section{SMARTPHONE DAILLY ACTIVITY}

The question aims to determine the direction of media design. As many as $24 \%$ of respondents prefer to seek information or knowledge on the internet through smartphonenya and $76 \%$ of respondents prefer to play games with smartphonenya. The answer to seek information or knowledge on the internet via smartphone will lead to the design of the website, while the answer to play games with smartphones lead to game design.

\begin{tabular}{|l|l|l|}
\hline Question & Seeking information & Gaming \\
\hline $\begin{array}{l}\text { What is your daily activity } \\
\text { with your smartphone? }\end{array}$ & $\mathbf{2 4 \%}$ & $\mathbf{7 6} \%$ \\
& 12 respondents & 38 respondents \\
\hline
\end{tabular}

The results determined that it would be more appropriate to design the game. For the design criteria is filled by 38 respondents who previously had a game play as an activity they liked to do with their smartphone. The genre is suitable for the target of research is a genre that is carried by the game plants vs zombie strategy as compared before.

\section{Creating a new icon for teenagers through game}
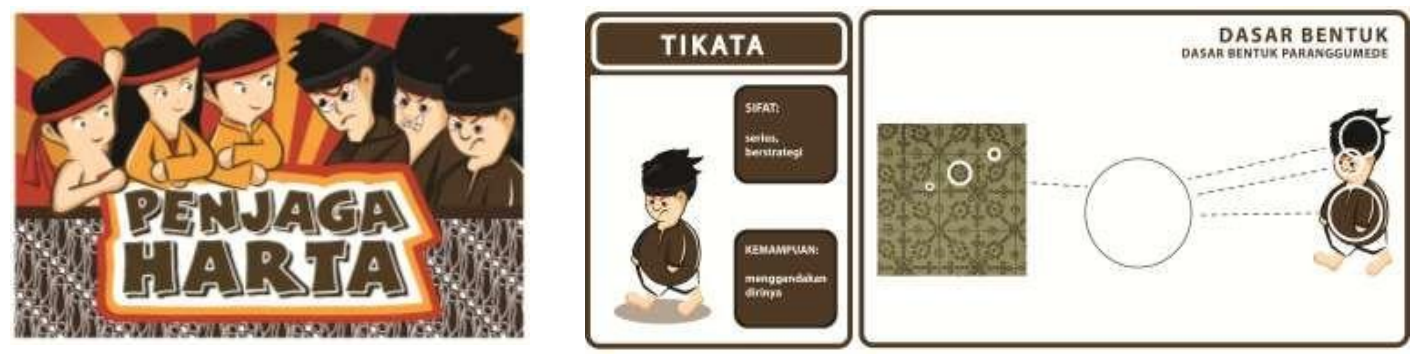

Picture 04. An icon to introduce the rule and the game 

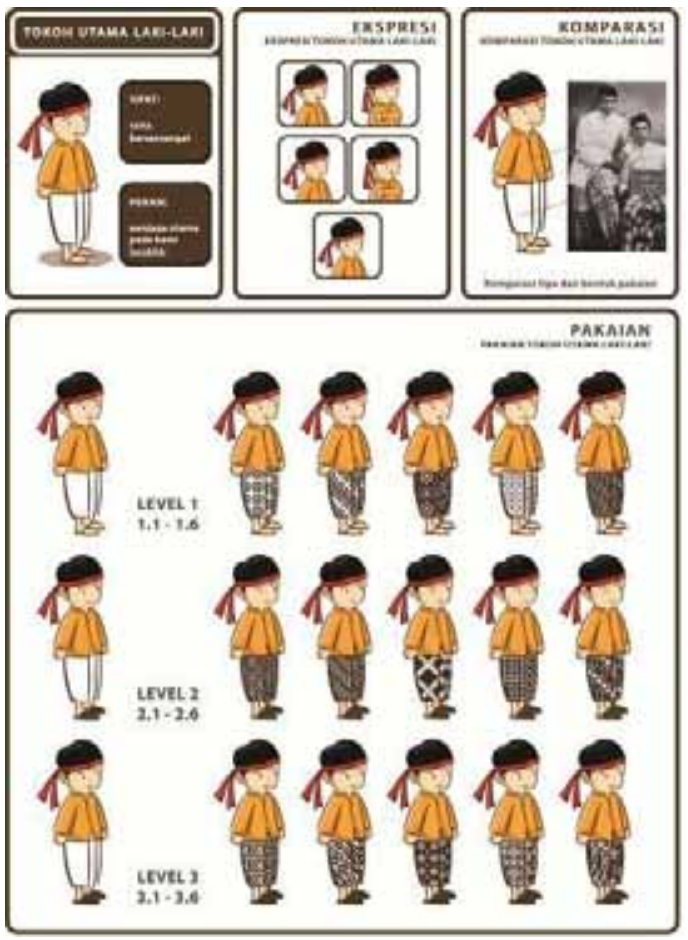

Picture 05. Levelling game indicate the level of meaning
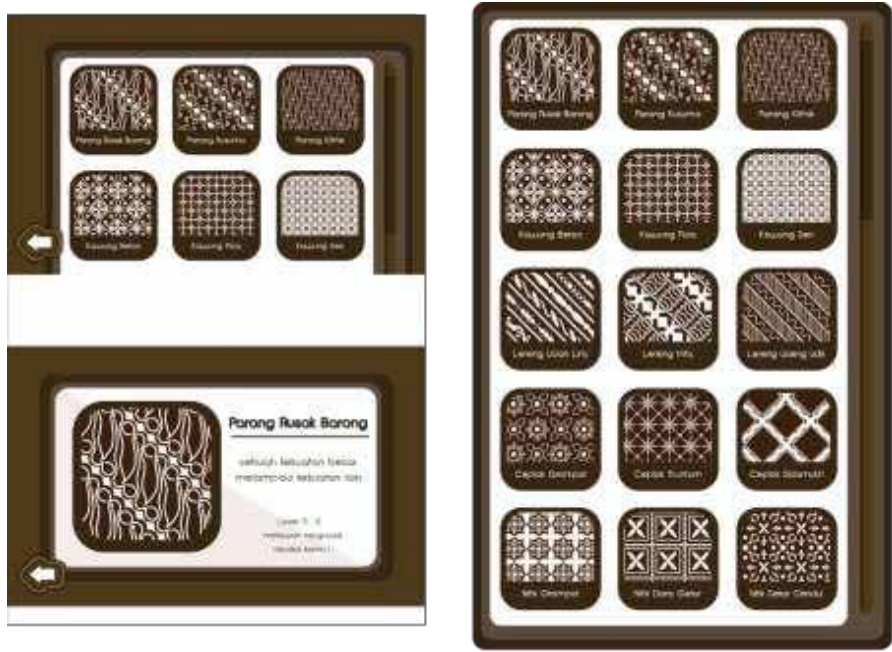

Picture 06. Categorization motif for further information
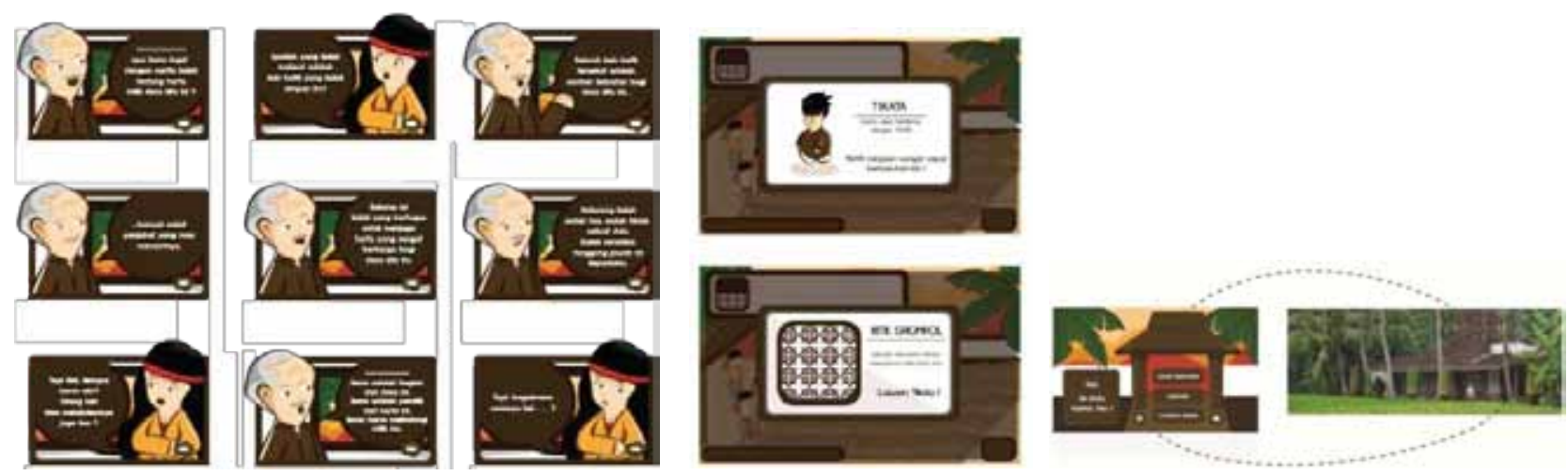

Picture 07. Storytelling about convertion Batik into a game 


\section{CONCLUSION}

Batik is Indonesian culture. In today's society Indonesia already loves batik but with the wrong perception. Today people love batik just because batik looks interesting. Batik has a value more than that. Batik as a culture has a meaning that should be loved by Indonesian people especially target consumers average 15-18 years old. Batik as Indonesian culture should be understood and loved properly. The meaning of batik rarely appears in every discussion of batik. When it appears it usually is very heavy information. This time the meaning of batik comes in a different and more fun way. Through game design in virtual reality, teenagers could learn and understand the meaning of Batik with easy and fun way. So in the future, Batik as a part of Indonesian Culture will not be lost.

\section{REFERENCES AND FURTHER READING}

Crawford, Chris. 1997. The Art of Computer Game Design. United State of America: Washington State University Press.

Hamzuri, Drs. 1989. Batik Klasik. Jakarta: Djambatan.

Fiske, John. 2012. Pengantar Ilmu Komunikasi. Jakarta: Rajagrafindo Persada. Gagne, Robert M. 1973. Information Processing Learning Theory. Englewood Cliffs. Hurlock, Elizabeth B. 1956. Developmental Psychologi A. Life-Span. New York: McGraw-Hill Book Company.

Prasetyo, Dr. Anindito. 2010. Batik Karya Agung Warisan Budaya Dunia. Yogyakarta: Pura Pustaka.

Ramadhan, Iwet. 2014. Cerita Batik Iwet Ramadhan. Jakarta: Erlangga.

Roojen, Pepin van. 1999. Batik Design. Jakarta: Pepin Press.

Samsi, Sri Soedewi. 2011. Teknik dan Ragam Hias Batik Jogja dan Solo. Jakarta: Titian Foundation.

Sarwono, Sarlito Wirawan. 2010. Psikologi Remaja. Jakarta: Rajawali Press. Wulandari, Ari. 2011. Batik Nusantara - Makna Filosofis, Cara Pembuatan, dan Industri Batik. Yogyakarta: Penerbit Andi. 